Bond University

Research Repository

\title{
Third places in transit: Public transport as a third place of mobility
}

\author{
O'Hare, Daniel
}

Published in:

Rethinking Third Places

DOI:

$10.4337 / 9781786433916.00018$

Licence:

Other

Link to output in Bond University research repository.

Recommended citation(APA):

O'Hare, D. (2019). Third places in transit: Public transport as a third place of mobility. In J. Dolley, \& C. Bosman (Eds.), Rethinking Third Places: Informal Public Spaces and Community Building (pp. 174-195). Edward Elgar Publishing. https://doi.org/10.4337/9781786433916.00018

\section{General rights}

Copyright and moral rights for the publications made accessible in the public portal are retained by the authors and/or other copyright owners and it is a condition of accessing publications that users recognise and abide by the legal requirements associated with these rights.

For more information, or if you believe that this document breaches copyright, please contact the Bond University research repository coordinator. 


\title{
$<\mathrm{CN}>$ Chapter $10 .<\mathrm{EN}><\mathrm{CT}>$ Third place in transit: public transport as a third place of mobility $<$ AU $>$ Daniel O'Hare
}

\author{
$<$ A $>$ THE RISE AND RISE OF COMMUTING: SHIFTS IN WORKPLACES, URBAN \\ FORM AND LIFESTYLES
}

Oldenburg's alternative description of third places as 'the great good place' sets a high bar for public transport to aspire to. Oldenburg himself has set a huge hurdle for any consideration of public transport as a third place. He writes (Oldenburg 1997, p. 7) that 'Life without community has produced, for many, a lifestyle consisting mainly of a home-to-workand-back-again shuttle. Social well-being and psychological health depend upon community'. For workers, students and others who spend time on public transport, much could be gained by cultivating community in transit vehicles and stations. Oldenburg's evocation of third places was a reaction to the period of peak suburban sprawl, whereby daily life in North American cities was dominated by a long car-commute - the daily shuffle - between low density residential-only suburbs (or small towns and villages) and workplaces. By this time, workplaces were becoming less concentrated in city centres or 'downtowns'. Through the suburbanisation process of 'making a middle landscape' (Rowe 1992), workplaces were becoming dispersed through the rise of office parks and standalone major employers. These isolated, monocultural working environments lacked the diversity and richness of city centres, depriving employees of the access to a variety of third places that a worker might find within a short walk during their lunchbreak in a city centre - places such as a park, a gallery, a hidden-away café. In the new middle suburban landscape, the office park provided only an alternative form of lack of diversity, so commuters' lives could be split by an unrewarding drive between a residential desert and an office desert where few other human needs could be met or interests stimulated.

Oldenburg seems to write more of the office worker's commuter lifestyle than that of the blue collar worker. White collar workplaces had been concentrated in city centres, but by the 1990s there were increasing signs that major cities were developing into polycentric city regions (Garreau 1991; Simmonds and Hack 2000) or that they should be restructured to do so (Calthorpe and Fulton 2001).

Emerging 'edge cities', new clusters of economic activity noted by Garreau (1991), initially lacked the diversity of traditional city centres and it has taken decades for some of them to be 'refined' into genuine town centres with attractive streets and good public transport. The literature traces the transition of Tyson's Corner, outside the Washington DC beltway, from incremental unplanned urban fringe automobile stop-off to integrated town centre over the past half-century. Connection of this former 'non-place' to the Washington DC Metro, combined with dense redevelopment and the insertion of a walkable street grid is described by Levy (2017).

Although there is widespread agreement that public transport is important to the social and environmental sustainability of our cities, public transport use is comparatively low in Australian cities, being the chosen mode for only 27 per cent of all trips to work in Sydney at the 2016 census, and below 20 per cent in Australia's other major cities (Charting Transport 2017). Only 11 per cent of all trips in Sydney are by public transport. This is low by 
comparison with the mode share of public transport (all journeys, not just to work) in world cities in 2011: Hong Kong 80 per cent, Seoul 63 per cent, Paris 62 per cent, Tokyo 51 per cent, Singapore 44 per cent (Anon. 2011). In some cities with similar public transport mode shares to that of Sydney's journey to work (i.e. around 27 per cent), similar or greater percentages of trips are by walking (for example in Bangalore, London, New York) rather than the majority being by private car as in Australian and North American cities, where densities are generally lower and a century of zoning has restricted mixed use development until recently.

Oldenburg's implied binary distinction between home and work was arguably at its most pronounced during the mid-twentieth century. Earlier, in the industrial revolution, work had become more separated from home as large numbers of workers became employees of large companies. Rather than artisans working below their homes, or shopkeepers 'living over the shop', these industrial workers left home each day to work in their mines or factories of employment. But home was often nearby, for example down the street or around the corner, and walking was a dominant transport mode for employees to get to work.

The rise of health problems for families living too close to these 'satanic mills' led to the suburbanisation of housing. At the same time, new forms of energy and technology enabled the introduction of mass public transportation by train and tram. The consequence was that work and home became separated, and the daily commute became a feature of daily life. With the growth of private car ownership in the second half of the twentieth century, the commute became less communal and more individualised.

Many commuters choose to use their private car rather than public transport for reasons including privacy, security and lack of tolerance for travelling with people of different socioeconomic status. The average car commute in Sydney is 26 minutes while the average public transport commute is considerably longer at 61 minutes per day (BITRE 2016). These minutes are valuable to the individual, so their commuting space has the potential to be a third place, whether it is a shared mass transit vehicle or an individual private car.

Young adults in Western countries are driving less than their parents. In the Australian state of Victoria, the proportion of 17-25-year-olds having a driver's licence fell from 77 per cent to 67 per cent between 2000-2001 and 2011-2012, while the proportion of licence-holders in the 25-64 years age group remained steady at 95 per cent (Delbosc and Currie 2013b). Similar falls in young age groups attaining licences were recorded in nine developed countries, most notably in Sweden and Norway, 'where licensing of young adults dropped by over 10\% between the mid-1980s and the late 1990s (Berg, 2001)' (in Delbosc and Currie 2013a, p. 272). In the UK, males aged 17-20 holding driver's licences fell from a 1993 peak of 54 per cent to fluctuate between 30-40 per cent in the years 2004-2012. In the same period, the equivalent statistics for UK females aged 17-20 fell from 41 per cent in 1993 to 25 per cent in 2004, recovering to 30-35 per cent between 2009 and 2012 (Berrington and Mikolai 2014).

A survey of 200 young Australian adults reveals that, while the high cost of motoring is the biggest reason for the decline in licence-holders, other major reasons include the ability to get around without a car and the ability to keep in contact with friends using social media (Delbosc and Currie 2013b). There are strong signs that this generation values their time, the experience of walkable neighbourhoods, and staying connected to friends and the world through their Internet-connected devices, which cannot be fully utilised while driving. The private car is no longer regarded by young urban people in developed nations as the primary means of establishing an independent lifestyle or symbolising status. As discussed later, trends towards less driving are predicted to persist because new communication technology substitutes for driving and supports alternative transportation (Davis and Dutzik 2012). The 
alienating daily auto shuttle decried by Oldenburg is being rejected, and so lively walkable neighbourhoods with good public transport are likely to be in greater demand.

\section{$<$ A $>$ THIRD PLACE, OR MOBILE SECOND PLACE FOR WORK?}

The division between work and other activities - and other places - is no longer as definitive as when Oldenburg first wrote on third places. New technology and changing labour practices have made work more portable, so that it is not unusual for some work to occur amongst other activities at home, on holiday or at your kid's sporting match. Or while you are travelling on public transport to your official workplace. In their study of 'travel time use in the information age', Lyons and Urry (2005) acknowledge the blurring of previous distinctions between 'travel time and activity time' (Lyons and Urry 2005 p. 263) and between 'home and away', so that 'people can be said to dwell within mobilities' (Lyons and Urry 2005 p. 267). New information and communications technology enables passengers to be 'at home' on public transport because of the ability 'to make more flexible and extensive use of their time on the move' (Lyons and Urry 2005 p. 263). People thus increasingly make productive and enjoyable use of their time while travelling, rather than passively enduring the journey as they await arrival at the destination.

For long commutes, intercity rail services are reportedly beginning to rival everyday commuter public transport services, due to quality, convenience and price competitiveness (Rose 2012). On-board digital services make intercity commuter trains in Europe, North America and Asia ideal mobile workplaces (Lauber 2018). Plamondon (2009), a consultant engineer and writer, provides great detail on his $200 \mathrm{~km}$ twice-weekly commute from his home in central Oregon to a client's workplace in Portland's outer metropolitan area across the state border in neighbouring Washington. He found the train well-equipped to support what we would call third place activities as well as work activities: it was comfortable, seats had tray tables and AC jacks for his laptop, mobile phone reception was good, he could walk around and stretch his legs during the journey, and there was a dining car for use as an alternative workspace or for eating, drinking, relaxing or socialising. He used the uninterrupted travel time to complete concentrated bursts of writing. If he was tired on the homeward journey he could watch an onboard movie or stream a podcast. The crew were friendly and got to know him; the railway station staff were also friendly: they advised him of the best place to park his car and kept an eye on it for him while he was away. Plamondon's experience, rich in third place options, is one that many commuters on regular, shorter everyday services would like to have available to them (including this author).

Hustle Juice, a website established to support footloose workers, describes wellequipped intercity trains as ideal co-working spaces, where location-independent workers can work in comfortable and convenient surroundings while seeing the countryside and meeting new people for friendship and potential business collaboration or exchange (Lauber 2018). Some of these high-speed intercity trains are more like replacements for intercity flights, rather than regular public transport routes for any but the most mobile or highly-paid workers who live in one city and work in another.

\section{$<$ A $>$ TRAVEL TIME AS A GIFT RATHER THAN A COST?}

A big part of the public transport experience is waiting: the wait at your stop or station and at any interchange points along the journey. And the journey itself may take a long time (cf. the average 61 minute commute in Sydney). While there is a long tradition in transportation 
policy and research of portraying travel time as a cost or penalty to commuters, there is emerging knowledge that travel time can be 'perceived and experienced as a gift rather than a burden' (Jain and Lyons 2008 p. 81). While this reconceptualisation seems to accord with third place thinking regarding public transport, the debate indicates that the issue is far from settled.

News and social media exchanges in 2013-2014 show the diversity of opinion, with some supporting third place arguments and some supporting speed and convenience. A member of the Portland Streetcar Citizens Committee, quoted in a local newspaper, defends an 18-minute service frequency with the opinion that '... frequency is an overrated thing. Let's say there's a 20-minute [wait]. You can look on your phone, wait inside and have a beer' (Fry, requoted in humantransit.org 2013). This drew some strong reactions, including 'I'm glad Mr. Fry has such a forgiving employer, spouse, extended family, dining companions, clients ... who don't mind him being late, but also a little drunk' (humantransit.org 2013). Others note how real-time knowledge of the location and timing of your streetcar gives passengers freedom to manage their time.

Another essential requirement for third place outcomes is that public transport allows the passenger some freedom. Information technology via mobile phones and real-time digital display boards is giving people more information on services and more ability to make their own choices about the times, routes and experiences offered for their trips. Access to realtime information on the location and timing of a bus lets us know how much time we have available to either rush or enjoy our walk to the station (Walker 2012). This can have a liberating effect that is beneficial to the workings of our local streets as third places, particularly offering spontaneity to be accommodated. For example, we would know if we have time to stop and talk following a chance meeting with a friend or acquaintance in our community on our walk to our bus. User control, over their travel and environment, contributes to higher levels of satisfaction and even enjoyment of commuting (Paez and Whalen 2010).

\section{$<$ A $>$ A THIRD PLACE FOR WINNING FRIENDS AND LOVERS $<$ quotation $>$}

Bus stop, bus goes, she stays, love grows

Under my umbrella. (The Hollies 1966)

$<$ quotation $>$

The young lovers in the Hollies' 1966 pop song (Gouldman 1966) found the bus stop the ideal place to initiate a spontaneous romance during an everyday activity, confirming that a bus stop could bring people together in a neutral space where accidental life-changing encounters were possible. High school students also have a record of using bus stops, railway stations, trains and trams as venues for embarking on their romantic lives. Half a century after the Hollies' bus stop song, Zoe Folbigg's (2014) article, 'How I found love on the 8.21' confirms that life-enriching encounters on public transport are still possible. For Folbigg and the Hollies' opportunistically courting couples, public transport stops and vehicles delivered on their potential to be a special place: 'a great good place' in Oldenburg's words.

Although there is very scarce refereed literature on public transport romances and friendships, there is a rich vein of ephemeral literature on such third place companionship encounters. The Sydney Morning Herald, over several decades, has published 'Column 8' contributions from readers who travel from the Blue Mountains to Sydney daily in friendship groups formed spontaneously on the train. Some just sit and read their books and newspapers after exchanging friendly greetings, while others play cards or board games, and celebrate birthdays or Christmas with a cake. 
Russell's (2012) research into Wellington (New Zealand) commuters gives the researcher's own eyewitness account of small groups of passengers enjoying carefully prepared Christmas celebrations around the tables between the facing seats in their train carriages. The seating configuration is supportive of commuter choices in favour of social interaction. Given the importance of cafés and bars to relaxation and sociability, as noted in the third place literature, it is arguable that such facilities should be a standard inclusion in stations and longer-distance commuter trains.

Jensen (2015) describes the mobile communities of public transport in a paper entitled 'The making of Multiple Mobile Places in everyday train commuting'. She observes how Danish commuters produce what Oldenburg calls third place through 'the routines and rhythms of the train' (Jensen 2015 p. 7). As well as 'individual practices of regeneration, relaxation, daydreaming and sleeping' (Jensen 2015 p. 9), commuters make acquaintances and develop a range of classifications of intensity of interaction, ranging from 'mobile others' (with little or no interaction), through to increasing degrees of interaction classified as 'mobile withs' (whom we might call 'friends on the train') to 'mobile friends' (where the friendship becomes extended into life beyond the train) (Jensen 2015 p. 8, Jensen's italics).

\section{$<$ A>COURTESY: CUSTODIANS AND CURATORS OF THE MOBILE THIRD PLACE}

Public transport as third place requires an atmosphere of 'civility', whereby 'the rider feels respected as a customer, as a citizen, and as a human being' (Walker 2012 p. 29). The basic conditions of civility are provided by the operator, including a quality service, timeliness, value for money, safety, security, cleanliness and comfort (Walker 2012).

Oldenburg and others write of the role of the staff of third places in creating a congenial atmosphere to enable people to feel at home. The staff who historically 'curated' the public transport experience have been disappearing for several decades due to cost-saving and replacement by technology. The shedding of station staff and on-board staff has changed the travel experience. We rarely encounter a ticket seller as we buy our tickets from a machine or top up our travel card automatically by direct debit from our bank account. Guards and conductors on trains, trams and buses have joined the ranks of obsolete occupations. Until their abolition in the 1990s, Melbourne's tram conductors - the 'connies' - created a welcoming atmosphere and provided travel directions and other information to passengers on 'their' trams. Automation has replaced these hospitality services, enabling efficiencies but also reducing security.

Urban transit authorities show support for the sociability and civility of public transport with behaviour management campaigns to encourage passengers to avoid anti-social behaviour (Russell 2012). These include Transport for London's 'considerate traveller' campaign, Philadelphia's 'dude it's rude' posters and Queensland Transport's 'super simple stuff' etiquette poster series, and similar campaigns in Perth, New York, Vancouver, Toronto, Tokyo, Singapore and many other cities.

Trains in some cities have introduced identified 'quiet' carriages in which passengers are expected to socially enforce the absence of loud conversations and other noise such as listening to music without headphones. Whether or not voluntary quiet carriage compliance is observed depends very much on the social characteristics of the particular train line and the culture of the particular city. Sydney's quiet carriages are strictly enforced by the passengers while 'quiet carriages' on South East Queensland's Gold Coast line are routinely ignored by both passengers and rail staff.

The ability to personalise a public space enables the user to feel more comfortable by exercising choices over their environment. The appeal and social value of movable seating in 
public open space has been noted as far back as Whyte's (1980) study of the social life of small urban spaces, and reinforced by Gehl (2010) and others. Such 'personalisation' could be put to use in public transport stations, but also apply to public transport vehicles. Some trains, such as Sydney's double-deckers, enable passengers to choose a more or less sociable setting, and a forward or rear-facing view, by offering reversible seating in the carriages.

Public uproar greeted an announcement in 2018 that Sydney's new intercity trains, servicing longer-distance commuters travelling up to four hours return each day, would not have reversible seats (also known as 'flip seats'). A media report (one of many) stated that 'internal documents released under freedom of information laws show why the state's lead transport agency chose fixed seats for the new intercity trains despite its own research revealing 'a strong customer appeal and usage of reversible seating' and a perception that fixed seating was a 'backward step' (O'Sullivan 2018 n.p.). Costs, weight, maintenance requirements, capacity, safety and procurement issues were cited among the reasons for the change. Opposition was not mitigated by the transport agency spokesperson citing several new benefits that support 'third place' performance at both an individual and social level, including 'wider seats, arm rests and wider aisles, [and] amenities like tray tables and charging outlets for mobile devices' as well as 'two sets of seats ... at either end of each carriage which would allow passengers travelling in groups to face each other' (cited by O'Sullivan 2018 n.p.). Selling the new seating arrangements to the public, with 'half the seats facing in one direction and the rest in the other' is clearly a public relations challenge. The 235 public comments on the online story, interestingly did not give much attention to issues that might be considered 'third place' concerns, with the risk of motion sickness (from rearfacing travel) being the only consistent substantive point advanced. The limited scope of public comments indicates that the community of commentators has not been educated in relation to the third place values and potentials of public transport.

Another issue relating to user control over their transit space is that public transport passengers might appreciate the ability to raise or lower blinds to suit their preferences for sunlight and shade. Mehta and Bosson (2010) point out that personalisation is also affected by people's observation of whether a public space is well maintained, clean and free of vandalism. The other aspect of 'personalisation' is the individual touch that traders bring to their shop's presentation to the street, something that the research noted made these small businesses stand out in contrast to corporate conformity. In the case of a railway station, this type of personalisation tends not to be present as there is usually a standardised corporate identity for the transit service. Personalisation - and custodianship - can be imparted in smaller ways, however, by amusing notices posted by station staff or by dryly humorous announcements made by quirky station and train staff.

\section{$<$ A $>$ CONNECTING TRANSIT WITH WALKABLE PEOPLE PLACES}

Public transport, and in particular public transport stations and stops, could offer more third place experiences by adoption of some of Mehta and Bosson's (2010) findings regarding third places and the social life of streets. In the research of three Massachusetts main street centres around transit stations, they found that four physical characteristics facilitated human interaction in an urban third place: personalisation, permeability, seating and shelter (Mehta and Bosson 2010).

Permeability, an important urban design quality (Bentley et al. 1985), influences how connected a station feels within a local street. Although ticket barriers may be a practical requirement, it is possible to influence the visibility and openness of the station through visual permeability. Visual connectivity offers advantages for crime prevention through 
environmental design (CPTED) and enhances passengers' feelings of safety while awaiting their service (also see Chapter 6 this volume). Shelter is essential to the climate comfort and protection of people awaiting public transport. In winter, solar access and protection from wind and rain may be the priority, while in summer shade via awnings and trees will be needed, together with protection from tropical storms in tropical cities.

Mehta and Bosson's (2010) research of main street centres gives clues to the types of 'third place' businesses that might be encouraged within or immediately adjacent to public transport stations: coffee shops, bars, restaurants, bookshops and convenience stores. Their observations and interviews found that these places acted as 'meeting places or community gathering places', 'places where [people felt] welcome and the people were friendly and where they spent time in active and passive socializing (i.e. sitting in the presence of other people, watching people and their activities, etc.) with their neighbours, friends, and acquaintances' (Mehta and Bosson 2010 p. 788).

To attract passengers and to have a chance of being sociable third spaces, public transport nodes need to be highly walkable. Lavadhino (2017 pp. 170-171) stresses that 'public transport never happens on its own; it is sparked by walking, and it needs walkenabled environments to thrive.' Citing efforts by public transport operators in Grenoble and Bordeaux to boost patronage by upgrading pedestrian catchments, she proposes 'a new paradigm of a pedestrian-driven multimodal city, a city where the comfort of the walking experience plays a key role in choosing public transport over other modes of transportation' (Lavadhino 2017 p. 171, emphasis added). She notes that pedestrian-supportive public transport precincts may result in movement about the city being seen as a pleasure rather than an obligation (Lavadhino 2017 p. 171).

Travel by public transport includes more than the time spent on each public transport vehicle between the passenger's origin and destination. Walking and waiting time are part of the overall trip. In an impoverished urban environment, time spent walking and waiting can be seen as 'lost' or 'wasted' time. Alternatively, walking and waiting can be seen as personal leisure and social opportunities to 'grab a coffee, catch up with friends, do some shopping or simply connect with the city through walking.... If well equipped with amenities that add value to these break times, public transport nodes stop being dull places where captive people kill time while waiting, and become places in which people actually enjoy spending time' (Lavadhino 2017 p. 173).

Lavadhino's 'in-between mile approach' in Grenoble sought to extend the attractive walking catchment of public transport and the acceptable modal interchange distance to a 10 15 minute walk by creating an experiential setting 'designed to empower people to create their own meanings to the acts of waiting and switching between travel modes while bringing joy and delight in the process' (Lavadhino 2017 p. 174, emphasis added). Temporary physical interventions were supported by mobile phone apps to improve people's knowledge of the area and the opportunities it offered. Functional walking corridors to and between public transport nodes, Lavadhino argues, need to be 'blend[ed] together to coalesce into a unified sense of place in the minds of the users', and this is achieved through combining 'three core ingredients ... things to do, people to meet and comfortable places to dwell' (Lavadhino 2017 p. 174). An important element of the 'nearness dynamics' of public transport nodes is 'serendipity, the capacity of hosting chance encounters between diverse people' (Lavadhino 2017 p. 182 citing Merton and Barber 2003). The Grenoble experiment identified a wide range of such chance encounters between diverse people. A newly created parklet above the railway station became a rendezvous place for commuters, a picnic spot for nearby office workers, a play space for children after school, and a social space for formerly isolated middle-aged women in nearby public housing. Each of these activities is a 'third place' activity. Lavadhino (2017 pp. 182-183) proposes a 'habitability paradigm' in which 
the 'economy of place' is more important than the 'economy of speed' framework within which public transport is technically viewed.

\section{$<$ A $>$ THE EMERGENCE OF THE DIGITAL THIRD PLACE}

There is a long tradition of public transport passengers, particularly solo travellers, relaxing by spending their time reading books and newspapers. Now it is commonplace to listen to podcasts of radio programmes, recorded music and watch movies via mobile phones and tablet computers. Social networking via Facebook enables people to keep in touch with friends and family while they commute. With this technology we can manage our social interactions while we are on public transport.

The ubiquity of mobile phones greatly increases the opportunity for commuters to participate in social networking while on their journey. The passenger's seat even in a crowded train, provides them with a base from which to connect into a 'placeless' digital third place that is beyond the mobile third place in which they are travelling.

Mobile social networks provide a means for users of public transport to meet up with friends and assists accidental travelling companions to develop friendships. The operation of such networks in the third places of urban areas, investigated by Humphreys (2010), can be transferred from fixed urban spaces such as bars, to the public transit spaces of public transport. Humphreys' (2010) research studied the use of Dodgeball, since superseded by other location services including the Google Maps app and Snapchat's Snap Maps feature. The location-sharing capability of mobile social media provides a means of being automatically alerted to and then connecting physically with your social network when in geographic proximity. If you choose, time spent in stations and on transit vehicles can therefore be shared with people in your circle of acquaintances and friends. Lofland (1998, in Humphreys 2010 p. 768) calls this the 'parochialisation' of public space. In this way, the public spaces of public transport can take on a more intimate and welcoming character in which people are more connected with their friends.

The founder of Dodgeball illustrates how location services and New York City's finegrained street grid combine to enable subway users to readily adjust their walk home from the station in response to alerts that friends are walking nearby:

$<$ quotation>

Everyone walks [in New York City], so the paths we take are so fluid.... So it's kind of like we can change the way they experience a city, if only in a small way... I can't tell you how many times I've had the experience where it's an average Tuesday and I get out of the subway and my phone starts to get some signal and I'm walking home and someone is a block north so I walk that way instead of walking this way.... it's helping me meet up with people I normally wouldn't meet.... (Dennis Crowley, cited in Humphreys 2010 p. 769)

$<$ quotation $>$

These examples (also see Chapter 9 this volume) show how the public transport experience is able to be transformed into a third place by social media. These services could also be used by public transport users who wish to check the locations of, and make a side trip to, potential 'great good places' near their station or walking route. These services can also be used to avoid acquaintances, for example if you are aware that a friend or work colleague is at a particular end of the train platform, you might choose to go to the other end and board a different carriage if you wanted to just read rather than socialise.

It is becoming very common for public transport providers to provide free $\mathrm{Wi}-\mathrm{Fi}$ to support the digital life of the train commuter. Free Wi-Fi access can make the public transport 
stop or station more enjoyable while waiting, and make the trip on the transit vehicle productive or pleasurable, according to the experience desired by the commuter. Many of these providers only allow very restricted bandwidths, meaning that passengers might not be able to download videos and other visual content. Some, such as South East Queensland's Translink, terminate the passenger's access after a certain time or when a certain amount of data is used up. Similarly 'most Amtrak trains provide free Wi-Fi but do not support highbandwidth actions such as streaming music, streaming video or downloading large files' (Lauber 2018). Other train systems, as in the UK and Europe, have more bandwidth available but charge the passenger according to use (Lauber 2018).

The accelerating pace of digital technology promises to transform the public spaces of public transport into more socially-oriented 'hybrid spaces' in which social connections, digital information, and physical space are increasingly merged (Frith 2013 p. 250). Just as location-based mobile games (LBMG) can 'operate as an encouragement for people to engage in non-gaming behaviors like going to bars and historical sites' (Frith 2013 p. 249), gamification could be used to enhance the passenger experience of public transport by making it a more playful experience.

\section{$<$ A $>$ PUBLIC TRANSPORT AS PUBLIC SPACE: LEARNING FROM DISNEYLAND AND REKINDLING DESIRE FOR THE STREETCAR ... AND TRAIN, TRAM, BUS AND FERRY}

Nordahl $(2008,2012)$ argues that public transport should be fun (and therefore appealing and enticing to potential riders) and that public transport systems constitute an important part of the civic space of a city. He notes how designers and marketers make automobiles desirable and says that public transport should be designed and marketed in similar ways. Nordahl (2008) emphasises the experience rather than the efficiency and speed of public transport: most of the public transport vehicles he depicts are old rather than new, or forms of technology that were never taken up seriously for mass transit, such as monorails. His exemplar for captivating the public's interest in using public transport is Disneyland and some of the places and transit systems he extolls would not be out of place in Disneyland, for example San Francisco's iconic cable cars, which are noted elsewhere as more suited to tourists than to everyday commuters (Walker 2009).

The experiential focus needs to be balanced, nevertheless, with the practical need for speed and reliability of service: 'the romantic impulse towards slow transit wears away quickly if you have no choice but to rely on it all the time!' (Szarkowski, in Walker 2014). It seems unnecessary for us to have to choose between efficiency and experiential qualities like charm or 'sexiness', as if they were mutually exclusive. They are not, and we do not need to exclude one by prioritising the other.

The emphasis in much of the research on public transport user experience is focused on the individual public transport user and their individual experiences. Factors highlighted typically include the punctuality of service, perceived security, and the comfort and cleanliness of vehicles and waiting areas. But 'the opportunity to meet people' is also valued by some public transport users (Hine and Scott 2000 p. 222). A study of work commuters using public transport in Sweden's three largest urban areas found that talking to other passengers on the homebound commute attracted high levels of satisfaction (Ettema et al. 2012). The sociability of the transit experience is critical to whether public transport can truly be a third place. 
The more important argument that Nordahl (2008) makes is that public transport vehicles are civic space, as acknowledged by Walker (2009), a major critic of the 'Disneyland theory of transit': $<$ quotation>

Transit vehicles are not just transportation, they are civic space, and they must be designed as such. Most of the values that [Nordahl] elucidates and defends - such as scale, style, transparency, lighting, and connection to place - should be considered in every decision about the design, procurement, and fitting of transit vehicles. But these experiential values cannot expect to rule on matters such as frequency, speed, and staffing ... because those factors are the dominant cost-drivers of transit; they will always be governed largely by what provides the greatest possible mobility at the least possible cost. (Walker 2009 blog post)

$</$ quotation $>$

We have seen in other chapters that public spaces are important third places in our cities, towns and suburbs. Public transportation systems are worthy of attention in this book because public transport stations and vehicles are public places associated with mobility (Nordahl 2008). Hence public transport stations and vehicles are critical opportunities for third place activities to flourish.

\section{$<$ A $>$ CREATING DISTINCTIVE, PERSONAL AND SOCIABLE PUBLIC TRANSPORT 'PLACES'}

Public transport systems - the networks of stations and fleets of vehicles - contribute greatly to the sense of place of a city or locality. Sydney Harbour Ferries, San Francisco's trolley cars, London's Underground and many other public transport systems internationally, offer a distinctive experience of the city at the same time as contributing significantly to the character of the city. The modern London Underground logo, almost unchanged since 1918, projects a highly legible corporate identity as well as making a major contribution to the local and regional identity of the metropolis (Meggs and Purvis 2016). Butina-Watson and Bentley (2007, pp. 101, 124) argue that the high quality modern graphic design of the Underground extended far beyond legibility, to create a distinctive 'cultural landscape', 'presenting the Underground not just as a means of transport, but rather as a life-enhancing source of varied experiences' (Butina-Watson and Bentley 2007 p. 105). In this way, public transport users were encouraged to identify themselves as belonging to 'a public transport community' (Butina-Watson and Bentley 2007 p. 101). The design approach sought to develop a 'coherent place-identity' for each line (Butina-Watson and Bentley 2007 p. 109), while the consistency in overall system design 'helped to bind together the 'city of villages' which many felt London to be' (Butina-Watson and Bentley 2007 p. 124). All of these points can be related to third place ideas, because they all focus on creating a system for people to identify with and to make it the setting for daily life experiences beyond merely transit.

When new public transport lines are being designed, design decisions are made between the legibility and character of individual stations versus the corporate identity of the whole system. This was the case in recent additions to South East Queensland urban public transport infrastructure, where after some consideration of alternatives the decision was made in favour of consistent rather than individual design treatment of stations on (respectively) the Brisbane Busways that commenced in 2000 and the Gold Coast Light Rail which commenced in 2014. Such decisions follow the example set by the strength of the London Underground. The Paris Metro is a slightly different example, where there is a subtler balance between the consistent identity of the system and the variations seen in different locations and different 
eras of development. Purely by being maintained through the mid-twentieth century when other cities were tearing up their tram lines, Melbourne's extensive tram system has continued to contribute significantly to the city's identity. Its role in place attachment was even greater before the tram conductors ('the connies') were abolished in a 1980s laboursaving and cost-cutting move.

In other more recent systems, efforts are made to differentiate particular public transport lines, as in the different coloured lines of the Boston Subway (the Blue, Green and Red Lines). While being differentiated in colour for legibility and passenger wayfinding reasons, the distinctiveness enhances the identity of different corridors in the city. When Sydney's Eastern Suburbs suburban rail line opened in 1979, it established a line identity distinct from others in the system and this was further enhanced by each station being differentiated by its own boldly coloured signage so that passengers could recognise their stop at a glance.

It is a well-established urban design principle that people like to be able to control their environment (Whyte 1980; Lynch 1984). Many cities have introduced movable street furniture that enables the users of urban space to arrange it to meet their needs and to be physically and socially comfortable (as first established in Whyte's 1970s research on the social life of small urban spaces). Adoption of movable urban furniture seems not to be growing at the same pace in public transport vehicles, even being removed in the case of Sydney trains, as discussed above.

\section{$<$ A $>$ PLANTING SOCIAL CAPITAL IN A PERENNIAL THIRD PLACE}

A breakfast radio interview describes how a stationmaster-initiated garden built community pride in a Brisbane suburban railway station (Begley 2017). Feelings of ownership and belonging are expressed by the stationmaster, local train passengers and community members. Establishment of the garden gives the stationmaster a sense of custodianship of a significant public place and his pride communicates that to passengers and community members, who may either assist in the garden's establishment and maintenance or share in the sense of place while catching or disembarking from trains at the station. The interview reveals enthusiastic participation by passengers and other local community members who bring in plant cuttings from their own gardens and provide advice on what to plant where or on when to prune particular plants. The stationmaster notes other benefits such as people getting to know each other and the station staff, and the opportunity for social interaction, including having someone to confide in during times of trouble. It is clear that, through custodianship of the station, this stationmaster plays the role of third place host described by Oldenberg. Devoting a daily 30-45 minutes to gardening activities before and after his basic duties, the stationmaster reports that the results include reduced vandalism, including passengers intervening to deter intending vandals (Begley 2017). Given the recognition of this station garden in a state-level community award nomination, and the stationmaster's endorsement by his local Member of Parliament, the Queensland Rail Chief Executive, his regional supervisor, passengers and local community members (Begley 2017; Bennion 2017), it is surprising that this effective means of social capital building is not endorsed as a systemwide programme (see also Chapter 8 this volume).

A British example illustrates the challenges of community gardening at railway stations. A Somerset village station was known for its distinctive community garden for a quarter of a century until its elderly volunteer carers were defeated by old age and 'officialdom', finally abandoning the garden when required by the authorities to wear highvisibility vests and helmets while gardening on the platform (Kington 2007). After the garden 
became derelict, a local committee was formed to recreate it with volunteer work, dedicating it with a plaque to the original retired gardeners. Within weeks, contractors 'with strimmers and chainsaws' completely destroyed the garden in an incorrect interpretation of a maintenance contract. Examples such as this are not widely reported, but they show that the property management practices of the large transit companies can be incompatible with local values such as custodianship of sense of place.

Changes in public transport infrastructure may provide resources for other community uses that may deliver third places to a community over time. When a railway station is superseded by new lines or falling patronage, the station buildings can be (and are) used as community centres, craft rooms and other activities that invite in the local community. Disused railway yards may become available for gardens that invite the community in. A formal example is the development of a high standard public garden in Brisbane's former Roma Street railyards. The Roma Street Parklands have been professionally designed, built and managed, but volunteers assist in their running and maintenance, and nearby residents, workers and citywide users find this a valuable community space to meet, play and spend time.

A less formal example is the Railway Park Community Garden established in the former Queanbeyan railyards, near Canberra, in 2002 (Parsons 2017). Under the current management arrangements, 26 community members lease separate garden plots from the head lessee, Queanbeyan Sustainability Group, which in turn leases from the local council. 'Many people who garden at Railway Park live in small units or townhouses with little or no outdoor space suitable for growing food. The garden provides a place for them to grow food for themselves and an opportunity to mix with neighbours they might not meet in the ordinary course of their lives' (Parsons 2017). Plot holders and the broader community invite greater community participation through working bees and harvest and spring time open days. This public transport infrastructure is used as a new kind of third place - the community garden - that is separate from its public transport use.

New York's Highline is perhaps the best known example of a disused urban railway line being reborn as a community garden, walkway and meeting place. Beyond the garden and beyond the city, other disused railway lines in many countries provide a stimulus to community through rebirth as rail trails for walking and cycling, opening up nature and countryside for the enjoyment of local people and tourists travelling slowly by bicycle or on foot.

\section{$<$ A $>$ PIXELATING THE PERSON-TO-PLACE ATTACHMENT}

The view from the passenger seat is a taken-for-granted priority for many public transport passengers. As an infrequent traveller on Sydney Harbour Ferries over many years, I have been surprised that regular commuters could take their eyes off the spectacular view of the cityscape on the water and concentrate on a newspaper, book or mobile device. When the Gold Coast was selecting optimal routes for its new light rail system, a section of the community expressed a strong preference for a waterfront route because of the views of the beaches, rather than the selected route a block or so inland that services more people and connects into local centres. Brisbane's Citycat waterbuses also offer very enticing views of the city from its broad river, while smaller cross-river ferries bob along providing a very sensory experience appreciated through sight, sound, maritime smells and the feel of the subtropical breeze.

A clear view out of the public transport vehicle adds to the visual interest of the journey and connects passengers to the physical and social places through which they travel. 
Passengers need to be able to see out so that they know when their stop is coming up. In some neighbourhoods, a passenger might also need to be able to see out to ascertain whether it is safe for them to alight at a particular stop. In the case of school children or young adults, there may be a need for them to see if there is someone they wish to avoid at the stop or station, and a social decision may be made to 'stay on the bus' until the next stop or station. Equally, passengers feel safer and more comfortable when boarding public transport if they can see the people and behaviour on-board.

Public transport passengers are among the 'eyes on the street' (Jane Jacobs' timeless term) that provide safety through their passive surveillance of public places. In a notorious criminal case of child abduction in South East Queensland in the early 2000s (the Daniel Morcombe case), it was passengers' views from a bus window that contributed vital evidence that assisted the identification and conviction of the main suspect, because he and his car were sighted near the boy at the time of his disappearance from a bus stop. Had this event occurred five years later, the passengers might not have been able to see clearly through the advertising wrap that is now common on the region's Translink bus windows. Would the 'caring' observations of these bus passengers be possible in today's buses screened in by advertising film?

Advertising wrap is now commonly seen on the windows of public transport vehicles in cities around the world. Usually the reason given for applying the wrap is that the advertising revenue helps to subsidise the cost of public transport provision. Yet on some services, such as Brisbane's Citycat waterbuses and City Glider high-frequency buses, the wrap merely advertises the vehicle itself.

The public transport authorities who sign the contracts with the advertisers apparently believe that the reverse-dot-matrix film is see-through. In the brightest light it is largely transparent, appearing like a thin veil over the view. But in dull weather, at night time or in rain, it appears opaque. This deprives passengers of an outward view and makes it difficult for them to see when their stop is coming up. The advantages of the passenger view, ranging from the pleasure of the journey to the passive surveillance of the streets, are lost in return for a relatively small advertising revenue.

\section{$<\mathrm{A}>\mathrm{CONCLUSION}$}

This chapter demonstrates that the public transport experience - in trains, trams, buses, ferries, stops, stations and station locales - is, and remains, central to the concept of third place. Public transport has continued to constitute a very important element of the public places of our cities throughout the major changes in urban structure that have accompanied globalisation. Since Oldenburg introduced the third place concept in 1993, there have been major changes in the shape of cities and in the nature of work as a result of changing work practices and technological development. Cities have continued to evolve into polycentric city regions that offer more than the simple contrast between the central city workplace and distant suburban homes implied by Oldenburg. At the same time, the distinction between work and other activities has become blurred and technology enables - and employer and employee expectations demand - that many people undertake work activities away from the workplace, including while on their public transport journey. Neat distinctions between first, second and third places are less applicable now. Through all of this change, the need for work-related and study-related travel has not abated.

We have seen that commuting by public transport can be much more than the dehumanising shuttle that Oldenburg dismissively mentioned. Examples have been provided of commutes that are enjoyed rather than merely endured, where public transport travel time 
is more of a 'gift' than a penalty in commuters' daily lives. Given the time that so many people spend commuting, it is essential that such positive experiences become the norm rather than the exception. There is much work to be done for this to become reality. This is an exciting time for public transport research and development, particularly as the potential of information and communications developments is only beginning to be realised. Greater recognition of the potential of public transport to be a 'gift', to be enjoyed rather than endured, presents design opportunities for transforming public transport vehicles, stops, stations and neighbourhoods into truly enriching third places of mobility. It is essential that we design and manage them in a way that contributes to 'the great good life' that people deserve from their cities.

\section{$<$ A $>$ REFERENCES}

Anon. 2011 Passenger transport mode shares in world cities, Journeys (November) pp. 6070. Accessed 25 April 2018 at http://studylib.net/download/7972629.

Begley, T 2017 Community spirit grows in train station garden, ABC Radio Brisbane, 6 June. Accessed 30 April 2018 at http://www.abc.net.au/radio/brisbane/programs/breakfast/traingarden $/ 8593258$.

Bennion, B 2017 Station master nominated for Queensland Day award for garden work, Quest Newspapers 2 June. Accessed 30 April 2018 at

https://www.independent.co.uk/voices/columnists/miles-kington/miles-kington-the-railwaystation-garden-that-set-a-rival-village-apart-464377.html.

Bentley, I, A Alcock, P Murrain, S McGlynn and P Smith 1985 Responsive Environments: A Manual for Designers. Oxford: Architectural Press.

Berrington, A and J Mikolai 2014 Young Adults'Licence Holding and Driving Behaviour in the UK: Full Findings. London: RAC Foundation.

Bureau of Infrastructure, Transport and Regional Economics (BITRE) 2016 Five facts about commuting in Australia, information sheet no. 77. Canberra: BITRE.

Butina-Watson, G and I Bentley 2007 Identity by Design. London and Burlington:

Butterworth-Heinemann.

Calthorpe, P and W Fulton 2001 The Regional City: Planning for the End of Sprawl.

Washington DC: Island Press.

Charting Transport (blog) 2017 Trends in journey to work mode shares in Australian cities to 2016 (2nd edition). Accessed 25 April 2018 at

https://chartingtransport.com/2017/10/24/trends-in-journey-to-work-mode-shares-inaustralian-cities-to-2016/.

Davis, B and T Dutzik 2012 Transportation and the New Generation Why Young People Are Driving Less and What It Means for Transportation Policy. Published by Frontier Group and US PIRG Education Fund. Accessed 30 April 2018 at

https://uspirg.org/sites/pirg/files/reports/Transportation $\% 20 \& \% 20$ the $\% 20 \mathrm{New} \% 20 \mathrm{Generatio}$ n\%20vUS 0.pdf.

Delbosc, A and G Currie 2013a Causes of youth licensing decline: a synthesis of evidence, Transport Reviews 33(3), 271-290.

Delbosc, A and G Currie 2013b Exploring attitudes of young adults toward cars and driver licensing, Australasian Transport Research Forum 2013 Proceedings, October. Brisbane. Ettema, D, M Friman, T Garling, L Olsson and S Fujii 2012 How in-vehicle activities affect work commuters' satisfaction with public transport, Journal of Transport Geography 24, 215-222. 
Folbigg, Z 2014 How I found love on the 8.21, Daily Mail 4 January. Accessed 30 April 2018 at http://www.dailymail.co.uk/femail/article-2533460/How-I-love-8-21-A-dreary-dailycommute-handsome-stranger-aisle-story-make-heart-soar.html.

Frith, J 2013 Turning life into a game: Foursquare, gamification, and personal mobility, Mobile Media and Communication 1(2), 248-262.

Garreau, J 1991 Edge City: Life On The New Frontier. New York: Doubleday.

Gehl, J 2010 Cities for People. Washington, DC: Island Press.

Gouldman, G 1966 Bus Stop [Recorded by The Hollies]. On Bus Stop. Los Angeles: Imperial Records.

Hine J and J Scott 2000 Seamless, accessible travel: users' views of the public transport journey and interchange, Transport Policy 7, 217-226.

humantransit.org 2013 Quote of the week: the portlandia streetcar, Human Transit: the professional blog of public transport consultant Jarrett Walker. Accessed 6 December 2018 at http://humantransit.org/2013/02/quote-of-the-week-the-portlandia-streetcar.html.

Humphreys, L 2010 Mobile social networks and urban public space, New Media and Society 12(5), 763-778.

Jain, J and G Lyons 2008 The gift of travel time, Journal of Transport Geography 16, 81-89. Jensen, H 2015 The making of Multiple Mobile Places in everyday train commuting. Paper presented at the RC21 International Conference on 'The Ideal City: between myth and reality: representations, policies, contradictions and challenges for tomorrow's urban life' Urbino (Italy) 27-29 August. Accessed 7 May 2018 at http://www.rc21.org/en/conferences/urbino2015/.

Kington, M 2007 The railway station garden that set a rival village apart, The Independent 16 September. Accessed 30 April 2017 at

https://www.independent.co.uk/voices/columnists/miles-kington/miles-kington-the-railwaystation-garden-that-set-a-rival-village-apart-464377.html.

Lauber, K 2018 It's time to book a train as your next coworking space, Hustle Juice.

Accessed 25 April 2018 at https://www.thehustlejuice.com/travel/2018/2/13/railway-trainfor-coworking.

Lavadhino, S 2017 Public transport infrastructure and walking: gearing towards the multimodal city. Chapter 9 in Mulley, C, K Gebel and D Ding (eds) Walking: connecting sustainable public transport with health, Transport and Sustainability 9, 167-186. ISSN: 2044-9941 doi 10.1108/ S2044-994120170000009011. Accessed online 9 October 2017. Levy, J 2017 Contemporary Urban Planning. New York and London: Routledge.

Lofland, L (1998) The Public Realm: Exploring the City's Quintessential Social Territory. New York: Aldine de Gruyter.

Lyons, G and J Urry 2005 Travel time use in the information age, Transportation Research Part A 39, 257-276.

Lynch, K 1984 Good City Form. Cambridge, MA: MIT Press.

Meggs, P and A Purvis 2016 Meggs' History of Graphic Design (6th edn). Hoboken, NJ: Wiley.

Mehta, V and J Bosson 2010 Third places and the social life of streets, Environment and Behavior 42(6), 779-805.

Merton, R and E Barber (2003). The Travels and Adventures of Serendipity: A Study in Sociological Semantics and the Sociology of Science. Princeton, NJ: Princeton University Press.

Nordahl, D 2008 My Kind of Transit: Rethinking Public Transportation in America. Chicago: Center for American Places at Columbia College in association with The Elizabeth Firestone Graham Foundation. 
Nordahl, D 2012. Making Transit Fun! How to Entice Motorists from their Cars (and onto their Feet, a Bike, or Bus). Washington, DC: Island Press (126 pp) (e-book). ISBN: 9781610910446.

Oldenburg, R 1997 Our vanishing 'third places', Planning Commissioners Journal 25 Winter 1996-1997, 6-10. Accessed 18 December 2018 at plannersweb.com/wpcontent/uploads/1997/01/184.pdf.

O’Sullivan, M 2018 Cost, safety trumps passengers' desire for flip seats on new trains, Sydney Morning Herald 15 March. Accessed 30 April 2018 at https://www.smh.com.au/politics/nsw/cost-safety-trumps-passengers-desire-for-flip-seats-onnew-trains-20180302-p4z2ib.html.

Paez, A and K Whalen 2010 Enjoyment of commute: a comparison by different transportation modes, Transportation Research Part A (44) 537-549.

Parsons, S 2017 The community garden at Queanbeyan Railway Station, Canberra Times 9 January. Accessed 30 April 2018 at https://www.canberratimes.com.au/national/act/thecommunity-garden-at-queanbeyan-railway-station-20170109-gto0ft.html.

Plamondon, R 2009 Commuting by train on the Amtrak Cascades, high-tech writing and engineering blog. Accessed 25 April 2018 at

http://www.hightechwriting.com/amtrak_commute/.

Rose, J 2012 Amtrak gaining popularity among commuters who ride between Portland, Oregon City and Salem, The Oregonian/Oregon Live 5 March. Accessed 25 April 2018 at http://www.oregonlive.com/pacific-northwestnews/index.ssf/2012/03/amtrak_gaining_popularity_amon.html.

Rowe, P 1992 Making a Middle Landscape. Cambridge, MA: MIT Press.

Russell, M 2012 Travel time use on public transport: what people do and how it affects their wellbeing, unpublished PhD thesis, University of Otago.

Simmonds, R and G Hack (eds) 2000 Global City Regions: their Emerging Forms. London and New York: Spon.

Walker, J 2009 The Disneyland theory of transit. 17 April. Accessed 28 April 2018 at http://humantransit.org/2009/04/the-disneyland-theory-of-transit.html\#more-24693.

Walker, J 2012 Human Transit. Washington DC: The Island Press.

Walker, J 2014 Blog post, 28 July. Accessed 28 April 2018 at

http://humantransit.org/category/philosophy.

Whyte, W 1980 The Social Life of Small Urban Spaces. New York: Project for Public Spaces. 